EXTENDED REPORT

\title{
The German etanercept registry for treatment of juvenile idiopathic arthritis
}

\section{G Horneff, H Schmeling, T Biedermann, I Foeldvari, G Ganser, H J Girschick, T Hospach, H I Huppertz, R Keitzer, R M Küster, H Michels, D Moebius, B Rogalski, A Thon, for the Paediatric Rheumatology Collaborative Group}

See end of article for authors' affiliations

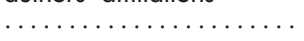

Correspondence to: Dr Gerd Horneff, Department of Paediatrics, University Medical Centre, 06120 Halle, Germany; gerd.horneff@ medizin.uni-halle.de

Accepted 21 March 2004 Published Online First 28 April 2004
Objective: To describe a registry set up to monitor children treated with etanercept in Germany and Austria.

Methods: Giannini's criteria, duration of morning stiffness, number of swollen, tender and contracted joints, adverse events, and reasons for discontinuation were assessed.

Results: 322 patients with juvenile idiopathic arthritis (JIA) and 12 additional patients with non-JIA rheumatic diagnoses were included. Therapeutic efficacy was observed from one month after treatment was started. The number of patients with significant improvement and the degree of improvement increased during the first year. The mean (SD) number of tender and swollen joints decreased from 9 (9) and 8.4 (9) to 3.0 (6.5) and 4.5 (7) after one month, and to 2.2 (5.5) and 3.3 (5.5) after three months; morning stiffness decreased from 45 (65) minutes to 12 (30) and 7 (19) after one and three months ( $p<0.001$ for all). Using Gianinni's criteria of $30 \%, 50 \%$, and $70 \%$ improvement, a therapeutic response in JIA patients was achieved in, respectively, $66 \%, 54 \%$, and $30 \%$ after one month, $78 \%, 61 \%$, and $38 \%$ after three months, and $83 \%, 72 \%$, and $52 \%$ after six months. Therapeutic efficacy was lower in patients with systemic onset arthritis. Overall tolerability was good: in 592 patient treatment-years there were 69 reports of adverse events in 56 patients, including one CNS demyelination. There were no opportunistic infections or lupus-like reactions. Treatment was discontinued in 53 JIA patients, in 25 because of lack of efficacy.

Conclusion: Etanercept treatment was safe and led to a significant improvement in most JIA patients resistant to conventional treatment.
J uvenile idiopathic arthritis (JIA; juvenile rheumatoid arthritis) is one of the most common inflammatory diseases in childhood and is a major cause of disability. ${ }^{1-3}$ Although the overall prognosis for most children with chronic arthritis is good, $5-10 \%$ of cases are refractory to conventional treatment, especially those with the systemic and polyarticular onset forms. ${ }^{45}$ Treatment resistant patients can develop severe joint destruction, growth retardation, and various adverse effects from long term treatment. Recently, the introduction of anti-tumour necrosis factor $\alpha$ (anti-TNF $\alpha$ ) treatment appears to have had a major impact on the outcome of patients with polyarticular JIA. An example of this type of drug, etanercept, has been approved and licensed for the treatment of active, treatment resistant polyarticular juvenile arthritis in patients aged at least four years following a single randomised controlled study. ${ }^{6}$ Subsequently, several reports of open label treatment of a limited number of children have been published, ${ }^{7-13}$ underlining the remarkable therapeutic efficacy of the drug.

In order to monitor prospectively the long term safety and efficacy of etanercept in children, a registry was set up by paediatric rheumatologists in Germany and Austria.

\section{METHODS}

The study protocol was evaluated by the ethics committee of the University Halle, and recruitment of patients started in January 2001. Written informed consent was obtained by the responsible physicians. The patient data were anonymised. In order to be eligible for treatment with etanercept, failure to respond to methotrexate was required..$^{14}$ The recommended dosage and treatment schedule of etanercept is $0.4 \mathrm{mg} / \mathrm{kg}$ body weight subcutaneously twice weekly. The patient's history, previous treatments, and concomitant therapy were documented. The diagnoses are listed in table 1 . The disease failed to respond to treatment with at least one, two, three, or more disease modifying antirheumatic drugs (DMARD) in $99 \%, 69 \%, 44 \%$, and $18 \%$ of patients, respectively.

For rheumatological follow up, the following data were collected $^{15-18}$ :

- physician's global assessment of overall wellbeing (visual analogue scale (VAS));

- parent/patient assessment of pain (VAS);

- functional disability (child health assessment questionnaire (CHAQ));

- number of joints with active arthritis defined as swollen and/or tender joints with limited range of motion;

- number of joints with limited range of motion;

- erythrocyte sedimentation rate (ESR);

- duration of morning stiffness.

Owing to the character of this study not all criteria were available from every point in time for every patient. To meet the definition of improvement at a certain point, patients had to have a $30 \%$ or greater improvement from the baseline in at least three of six available variables. They could also show a deterioration of $30 \%$ in no more than one variable. Though a small number of patients discontinued treatment, the data

Abbreviations: $\mathrm{CHAQ}$, child health assessment questionnaire; $\mathrm{JA}$, juvenile idiopathic arthritis; LCOF, last observation carried forward; TNF, tumour necrosis factor; VAS, visual analogue scale 
Table 1 Distribution of onset subtypes of patients with juvenile idiopathic arthritis (JIA) and non-JIA diagnoses

\begin{tabular}{ll}
\hline Diagnosis & $\begin{array}{l}\text { Number (\% of JIA } \\
\text { patients) }\end{array}$ \\
\hline All JIA patients & $322(100 \%)$ \\
Systemic arthritis (systemic onset JIA) & $66(21 \%)$ \\
Seronegative polyarticular JIA & $94(29 \%)$ \\
Seropositive polyarticular JIA & $39(12 \%)$ \\
Persistant oligoarticular JIA & $10(3 \%)$ \\
Extended oligoarticular JIA & $54(17 \%)$ \\
Enthesistis and arthritis JIA subtype & $26(8 \%)$ \\
Psoriasis and arthritis JIA subtype & $17(5 \%)$ \\
Unclassified JIA & $16(5 \%)$ \\
Non-JIA diagnoses & 12 \\
Sarcoidosis & 3 \\
NOMID & 2 \\
Reactive arthritis & 2 \\
CRMO & 1 \\
Crohn's disease & 1 \\
Behchet disease & 1 \\
Juvenile dermatomyositis & 1 \\
Uveitis (without JIA) & 1
\end{tabular}

*Additional diagnoses in JIA patients were documented as follows: uveitis (20), episcleritis (2), seizures (1), atopic dermatitis (3), asthma (2), recurrent skin abscesses (1), osteoporosis (5), anaemia (1), chondritis of the patella (1), hyper-IgE syndrome (1), hemiparesis (1), IgA deficiency (5), sudden hearing loss (1), panniculitis (1), hepatitis (1), autoimmune hepatitis (1), idiopathic lung fibrosis (1), keratoconjunctivitis sicca (1), proteinuria (4), mitral insufficiency (1), amyloidosis (3), coeliac disease (1), transposition of the large arteries (1), renal venous thrombosis (1), chronic otitis media (1), chronic tonsillitis (1), recurrent urinary tract infection (1), proctitis (1), gastritis (4), arterial hypertonia (3), scoliosis (1), allergic sensitisation (1), gastro-oesophageal reflux disease (1), macrophage activation syndrome (1), pericarditis (1), cataract (1), ambylopia (1), Cushing's disease (4), Kartagener's syndrome (1), febrile seizures (1), aseptic bone necrosis (1), recurrent obstructive bronchitis (1).

Patients with non-JIA diagnoses were followed for safety items only. CRMO, chronic recurrent multifocal osteomyelitis; NOMID, neonatal onset multisystemic inflammatory disease.

were expressed as the last observation carried forward (LOCF).

\section{Statistical analysis}

Differences in the efficacy assessment indices were evaluated using the Wilcoxon matched pairs test. For comparison between systemic onset and non-systemic onset JIA patients, the $\chi^{2}$ test was used.

\section{RESULTS}

Up to 31 October 2003, data on 322 JIA patients had been collected (table 1). These had been treated in 36 different paediatric rheumatology centres. Treatment with etanercept had been given for 1 to 48 months (mean (SD) length of treatment, 13.4 (10.5) months, median 12 months); 287, 229, 194, 139, and 106 patients had been treated for at least 6,12 , 18,24 , and 30 months, respectively. High disease activity is reflected by prolonged morning stiffness, large numbers of swollen, tender, or restricted joints, and a raised ESR and C reactive protein (table 2 ). Patients with systemic onset JIA had higher joint counts, CHAQ scores, and ESR values and more severe disease activity as assessed by their parents and by their physicians than patients with non-systemic-onset JIA.

\section{Therapeutic efficacy}

Significant improvements in the number of tender and swollen joints, duration of morning stiffness, and physician's and parent's global assessment was seen after 1, 3, 6, 12, 18, 24 , and 30 months $(\mathrm{p}<0.0001$ for all except for swollen joint count and ESR at 30 months $(\mathrm{p}<0.0005)$ and duration of morning stiffness at 30 months $(\mathrm{p}<0.001)$; Wilcoxon matched pairs test, table 2). A significant improvement in the CHAQ was observed after 6, 12, 18, 24, and 30 months $(\mathrm{p}<0.0001$ at $\mathrm{l}$ to 24 months and $\mathrm{p}<0.01$ at 30 months; Wilcoxon matched pairs test, table 2). Improvement was noted in $92 \%, 93 \%$, and $91 \%$ of patients after 6,12 , and 18 months of treatment, and in all patients treated for 24 and 30 months.

In all, 270 patients were treated for at least three months and were suitable for evaluation of efficacy according to the modified core set criteria. Of these, 32 discontinued treatment prematurely. At the time of discontinuation, a $30 \%$, $50 \%$, or $70 \%$ improvement was observed in 22,17 , and 10 patients. By "last observation carried forward" (LOCF) analysis, a therapeutic response according to the JIA 30, 50, and 70 criteria was achieved in $67 \%, 54 \%$, and $30 \%$ of the patients at one month, in $79 \%, 61 \%$, and $39 \%$ at three months, in $82 \%, 70 \%$, and $50 \%$ at six months, and in $80 \%$, $71 \%$, and $54 \%$ at 12 months, remaining at these levels thereafter.

Subtype analysis showed a markedly lower therapeutic efficacy in patients with systemic arthritis. After one month of treatment, $48 \%, 33 \%$, and $11 \%$ of patients reached a $30 \%$, $50 \%$, and $70 \%$ response, respectively. At three months the number of patients increased to $63 \%, 39 \%$, and $24 \%$ and subsequently remained stable (fig 1A). Of a total of 66 patients with systemic JIA, 17 (26\%) discontinued treatment. The reason for discontinuation was inefficacy of treatment in 14 cases $(21 \%)$.

In non-systemic JIA, the $30 \%, 50 \%$, and $70 \%$ levels of efficacy were reached by $74 \%, 60 \%$, and $34 \%$ of patients, respectively, after one month, and this increased to $90 \%, 82 \%$, and $64 \%$ at the end of the first year of treatment (fig 1B). Thus therapeutic efficacy started early and increased further during the first year of treatment. Although the number of patients achieving a 30\% response did not increase between three months $(79 \%)$ and 12 months of treatment $(81 \%)$, the degree of response increased during that period as the number of patients achieving a 50\% and $70 \%$ response increased by $10 \%$ and $16 \%$, respectively.

Of 256 non-systemic patients, 36 discontinued treatment $(21 \%), 11$ of these $(4 \%)$ because of inefficacy and 12 because of clinical remission as judged by the local physician. Patients with systemic JIA discontinued treatment because of a lack of response significantly more often than non-systemic patients $\left(p<0.0001, \chi^{2}\right.$ test $)$.

\section{Complete remission}

So far no criteria for complete clinical remission in JIA have been defined, but work on definition of such criteria is in progress. Fatigue-which is included in the American College of Rheumatology criteria for complete remission in rheumatoid arthritis-was not recorded. ${ }^{19}$ Thus complete response was defined by four of the following requirements: morning stiffness $<5$ minutes, no tender joint, no swollen joint, and a normal ESR (below $16 \mathrm{~mm} /$ hour). In all, 72 patients $(26 \%)$ reached this level of response.

Remission as defined by these criteria was achieved in eight patients with systemic JIA (13\% of all systemic JIA patients), in 14 with rheumatoid factor negative polyarthritis $(17 \%)$, in 11 with rheumatoid factor positive polyarthritis $(30 \%)$, in five with persistent oligoarticular JIA (62\%), in 14 with extended oligoarticular JIA (28\%), and in 20 with other subtypes of JIA (40\%). Patients with systemic JIA were less likely to experience complete remission. The presence of rheumatoid factor in patients with polyarthritis did not seem to influence the remission rate.

Treatment was discontinued in 14 patients because of long term remission as determined by their physicians. In seven of 
Table 2 Change in indices of disease activity after treatment with etanercept

\begin{tabular}{|c|c|c|c|c|c|c|c|c|}
\hline & \multicolumn{8}{|c|}{ Time (No of patients evaluated*) } \\
\hline & $\begin{array}{l}\text { Baseline } \\
\text { (314) }\end{array}$ & $\begin{array}{l}\text { Month } 1 \\
\text { (242) }\end{array}$ & $\begin{array}{l}\text { Month } 3 \\
\text { (225) }\end{array}$ & $\begin{array}{l}\text { Month } 6 \\
\text { (203) }\end{array}$ & $\begin{array}{l}\text { Month } 12 \\
\text { (152) }\end{array}$ & $\begin{array}{l}\text { Month } 18 \\
\text { (99) }\end{array}$ & $\begin{array}{l}\text { Month } 24 \\
\text { (78) }\end{array}$ & $\begin{array}{l}\text { Month } 30 \\
\text { (42) }\end{array}$ \\
\hline $\begin{array}{l}\text { Number of swollen joints } \\
\text { Patients with no swollen joint }\end{array}$ & $\begin{array}{l}8.4(9.0) \\
11 \%\end{array}$ & $\begin{array}{l}4.5(7.0) \\
23 \%\end{array}$ & $\begin{array}{l}3.3(5.6) \\
36 \%\end{array}$ & $\begin{array}{l}3.6(6.5) \\
45 \%\end{array}$ & $\begin{array}{l}2.6(4.7) \\
51 \%\end{array}$ & $\begin{array}{l}3.6(7.5) \\
50 \%\end{array}$ & $\begin{array}{l}2.4(3.9) \\
43 \%\end{array}$ & $\begin{array}{l}3.3(6.1) \\
48 \%\end{array}$ \\
\hline Number of tender joints & $9.1(9.5)$ & $3.0(6.5)$ & $2.2(5.5)$ & $2.6(6.7)$ & $1.7(3.5)$ & $2.7(6.1)$ & $1.8(3.3)$ & $1.7(3.1)$ \\
\hline Patients with no tender joint & $7 \%$ & $46 \%$ & $52 \%$ & $55 \%$ & $58 \%$ & $63 \%$ & $59 \%$ & $57 \%$ \\
\hline \multirow{2}{*}{$\begin{array}{l}\text { Number of joints with LOM } \\
\text { Patients with no joint with } \\
\text { LOM }\end{array}$} & $11.8(11.8)$ & $8.0(11.3)$ & $7.2(10.6)$ & $7.7(11.6)$ & $7.1(8.9)$ & $7.6(10.9)$ & $8.2(9.8)$ & $10.0(10.7)$ \\
\hline & $5 \%$ & $15 \%$ & $16 \%$ & $18 \%$ & $16 \%$ & $24 \%$ & $13 \%$ & $15 \%$ \\
\hline \multirow{2}{*}{$\begin{array}{l}\text { Number of active joints } \\
\text { Patients with no active joint }\end{array}$} & $10.2(9.5)$ & $5.3(7.9)$ & $3.8(6.3)$ & $4.4(7.7)$ & $3.1(4.6)$ & $4.8(8.5)$ & $3.9(4.6)$ & $4.6(6.9)$ \\
\hline & & $22 \%$ & $32 \%$ & & & & & \\
\hline \multirow{2}{*}{$\begin{array}{l}\text { Morning stiffness (minutes) } \\
\text { Patients with no morning } \\
\text { stiffness }\end{array}$} & $45(65)$ & $12(30)$ & $8(19)$ & $6(17)$ & $7(23)$ & $8(31)$ & $8(24)$ & $4(10)$ \\
\hline & $29 \%$ & $66 \%$ & $73 \%$ & $75 \%$ & $79 \%$ & $81 \%$ & $78 \%$ & $85 \%$ \\
\hline \multirow{2}{*}{$\begin{array}{l}\mathrm{CHAQ} \text { score } † \\
\text { Patients with } \mathrm{CHAQ} \text { score } \\
\text { of } 0\end{array}$} & $1.0(0.8)$ & NA & NA & $0.5(0.6)$ & $0.4(0.6)$ & $0.5(0.6)$ & $0.4(0.6)$ & $0.5(0.7)$ \\
\hline & $11 \%$ & NA & NA & $32 \%$ & $34 \%$ & $39 \%$ & $40 \%$ & $49 \%$ \\
\hline Patient's global assessmentł & $56(27)$ & $24(22)$ & $19(19)$ & $18(20)$ & $16(18)$ & $17(23)$ & $17(18)$ & $12(16)$ \\
\hline Patient's global $<10 \mathrm{~mm}$ & $6 \%$ & $38 \%$ & $46 \%$ & $48 \%$ & $54 \%$ & $56 \%$ & $53 \%$ & $61 \%$ \\
\hline Physician assessment & $67(25)$ & $32(26)$ & $26(26)$ & $24(25)$ & $20(23)$ & $23(27)$ & $20(21)$ & $20(24)$ \\
\hline Physician's global $<10$ mm & $2 \%$ & $27 \%$ & $40 \%$ & $42 \%$ & $52 \%$ & $44 \%$ & $39 \%$ & $57 \%$ \\
\hline ESR & $40(30)$ & $19(21)$ & $19(21)$ & $18(19)$ & $17(17)$ & $18(21)$ & $17(13)$ & 19 (17) \\
\hline Patients with ESR $<16 \mathrm{~mm} / \mathrm{h}$ & $22 \%$ & $62 \%$ & $63 \%$ & $64 \%$ & $68 \%$ & $66 \%$ & $61 \%$ & $54 \%$ \\
\hline \multicolumn{9}{|c|}{$\begin{array}{l}\text { Compared with pretreatment levels, significant improvement was noted in all data and all points of time: } p<0.0001 \text { for all except for swollen joint count and ESR a } \\
30 \text { months: } p<0.0005 \text {; duration of morning stiffness at } 30 \text { months: } p<0.001 \text {; CHAQ at } 30 \text { months: } p<0.01 \text {; Wilcoxon matched pairs test. } \\
\text { *Only data from patients with JIA who underwent assessment at the respective visit are included. } \\
\text { tThe range of scores for the CHAQ is } 0-3 \text { ( } 0=\text { best, } 3=\text { worst). } \\
\text { †A } 100 \mathrm{~mm} \text { scale was used to assess the patient's and physician's global assessment of disease activity }(0=\text { best, } 100=\text { worst). } \\
\text { CHAQ, child health assessment questionnaire; ESR, erythrocyte sedimentation rate; JA, juvenile idiopathic arthritis; } L \mathrm{M} \text {, limitation of movement. }\end{array}$} \\
\hline
\end{tabular}

these, however, the disease flared up after one $(n=3)$, two $(\mathrm{n}=3)$, and 11 months $(\mathrm{n}=1)$. A relation between treatment duration and relapse of the disease could not be demonstrated. Etanercept was reintroduced in five of these patient, resulting in the same efficacy as initially.

\section{Concomitant treatment}

Combination treatment with oral corticosteroids was used in 199 patients $(68 \%)$ and combination treatment with methotrexate in $235(80 \%)$. Corticosteroids were discontinued in 50 patients and methotrexate in 25. At the start of etanercept therapy, no difference was found between children treated with methotrexate and those without methotrexate with respect to disease duration, presence and duration of morning stiffness, number of tender, swollen or restricted joints, and values for ESR and $C$ reactive protein (data not shown). Comparison of the frequency or kinetics of the response to etanercept treatment showed no differences in patients treated with methotrexate in combination therapy compared with those without methotrexate treatment.

During follow up, the number of patients reaching a clinical condition in which there were no tender joints was greater in the combination group (at 12 months, 57\% v 48\%; at 24 months $67 \% \vee 42 \%$ ). There was no difference in the number of patients without swollen joints, without morning stiffness, or with an ESR below $16 \mathrm{~mm} /$ hour. However, patients treated with methotrexate and etanercept in combination were more likely to achieve complete remission (29\% $v 14 \%, \mathrm{p}=0.07, \chi^{2}$ test). The likelihood of patients with systemic onset JIA achieving complete remission was lower than in non-systemic-onset JIA $\left(12.5 \% \vee 31 \%, \mathrm{p}<0.02, \chi^{2}\right.$ test); $35 \%$ of non-systemic-onset JIA patients treated with etanercept and methotrexate in combination and 13\% of those without methotrexate achieved complete remission $\left(\mathrm{p}<0.02, \chi^{2}\right.$ test $)$.

In the combination group significantly fewer patients discontinued etanercept ( $17 \%$ v $30 \%, \mathrm{p}<0.01, \chi^{2}$ test), which reflected a lower rate of inefficacy $\left(7 \% v 15 \%, \mathrm{p}<0.05, \chi^{2}\right.$ test).

\section{Adverse effects and discontinuations}

During about 592 patient-years of treatment, there were 69 reports of adverse events in 56 patients. There were no opportunistic infections or lupus-like reactions, but there were 20 reports of infections or infection related events (table 3). Forty nine reports were unrelated to infections. There were 57 reports of non-severe and 12 reports of severe adverse events, including one case of pneumonia requiring mechanical ventilation, one carcinoma of the thyroid occurring in a 19 year old female patient after nine months of treatment, and a case of toxic epidermal necrolysis developing after a patient started using an oral contraceptive. In that case treatment with both the contraceptive and etanercept was stopped and the patient recovered completely. Etanercept was subsequently reintroduced without any problem. Treatment was permanently terminated because of adverse events in 11 patients (table 4). In one patient who suffered from aseptic meningitis and epilepsy before the diagnosis of JIA, febrile seizures occurred during rotavirus enteritis but the neurological status was unremarkable. Subsequently, demyelination was visible on magnetic resonance imaging (MRI), and oligoclonal bands were found in the cerebrospinal fluid. An extensive infection work up was negative. Etanercept was discontinued. Six months later the cerebral lesions were still present. 
A

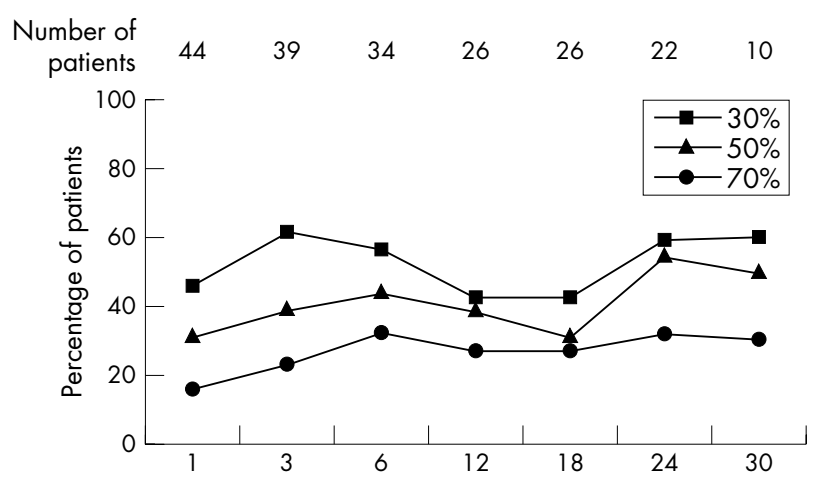

B

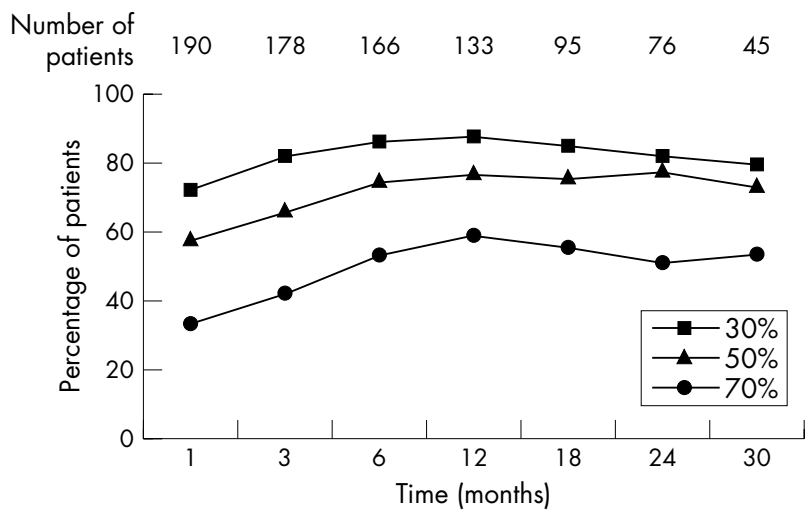

Figure 1 Incidence of 30\%, 50\%, and 70\% improvement in patients with juvenile idiopathic arthritis (JIA) receiving etanercept treatment, according to the core set criteria. Data on 275 patients are included. Analysis was undertaken by LCOF (last observation carried forward). (A) 48 JIA patients with systemic onset and a treatment duration of at least two months. Four patients were excluded because treatment had been discontinued earlier; in eight patients month 1 data were missing; eight patients with systemic onset JIA discontinued treatment prematurely. At last report, a $30 \%, 50 \%$, or $70 \%$ response level was reported in one, one, and two patients, respectively, while four were non-responders. (B) 222 JIA patients with non-systemic-onset. In 32 patients month 1 data were missing. The number of non-systemic-onset JIA patients who met the $30 \%, 50 \%$ and $70 \%$ response criteria exceeded the number of systemic onset JIA patients who met the core set criteria. Twenty four of 222 patients with non-systemic-onset JIA discontinued prematurely. At last report a $30 \%, 50 \%$, or $70 \%$ response level was reported in four, six, and eight patients, while only six were non-responders.

Treatment was temporarily discontinued in 12 patients. Adverse events resolved in all but two cases (itching (1), uveitis (1)). The adverse event reoccurred upon reintroduction of etanercept in one patient (itching).

Treatment was discontinued in 53 JIA patients and four patients with reactive arthritis, neonatal onset multiorgan inflammatory disease (NOMID), idiopathic uveitis, and infantile sarcoidosis (table 4 ). In 27 cases $(50 \%)$, this was because of inefficacy as judged by the responsible physician. Fourteen of these patients belong to the systemic arthritis subgroup. In 11 cases $(20 \%)$, treatment was discontinued because of adverse events as listed in table 4. One patient developed lymph node enlargement. In three patients treatment was discontinued because of uveitis. The joint disease was well controlled in these patients. Treatment was also discontinued in one patient with asymmetrical oligoarticular JIA (primarily classified as psoriasis and arthritis) who developed Crohn's colitis and in one who was diagnosed as having Takayasu's arteritis.
Table 3 Adverse events (69 events in 56 patients)

\begin{tabular}{|c|c|}
\hline Event & Number of patients \\
\hline \multicolumn{2}{|l|}{ Reported infections $(\mathrm{n}=20$ ) } \\
\hline Bronchitis, prolonged & 2 \\
\hline Infection, prolonged or with fever & 5 \\
\hline Herpes simplex labialis & 2 \\
\hline Varicella zoster virus infection & 1 \\
\hline Zoster & 1 \\
\hline Multiple mollusca contagiosa & 1 \\
\hline Stomatitis & 1 \\
\hline Rotavirus enteritis & 1 \\
\hline Septic arthritis following joint puncture & 1 \\
\hline Urinary tract infection & 1 \\
\hline Impetigo contagiosa & 2 \\
\hline Cellulitis & 1 \\
\hline Pneumonia & 1 \\
\hline \multicolumn{2}{|l|}{ Non-infectious reports $(n=49)$} \\
\hline Local skin reaction & 7 \\
\hline Eczema & 1 \\
\hline Raised liver enzymes & 7 \\
\hline Itching, exanthemata, urticaria & 6 \\
\hline Allergic conjunctivitis & 1 \\
\hline Scarring skin lesions & 1 \\
\hline Nausea, vomiting & 2 \\
\hline Leucocytopenia +/- thrombocyłopenia & 4 \\
\hline Abdominal pain and/or headache & 6 \\
\hline Dizziness & 2 \\
\hline Sleeplessness & 1 \\
\hline Hair loss & 4 \\
\hline Toxic epidermal necrolysis (contraceptiva) & 1 \\
\hline Oesophagitis & 1 \\
\hline Cholecystitis (sterile) & 1 \\
\hline Carcinoma of the thyroid & 1 \\
\hline Febrile seizure (during rotavirus enteritis) & 1 \\
\hline Demyelination, seizures & 1 \\
\hline Lymph node enlargement & 1 \\
\hline
\end{tabular}

\section{DISCUSSION}

This study provides data about the treatment with etanercept in more than 300 patients diagnosed with JIA. So far, this is the largest number of such patients reported. The major results of this study were as follows: first, there was a high response rate to etanercept in patients with JIA who were previously unresponsive to several anti-rheumatic drugs including methotrexate; second, there was rapid improvement after starting the drug (improvement was already clearly present after one month of treatment); third, there was a continuous increase in the number of patients responding and in the strength of improvement during the first year of treatment; fourth, the response rate was higher in patients with non-systemic-onset JIA than in those with systemic onset; fifth, only a few patients discontinued treatment; and finally, there were few adverse events.

This study confirms previous findings from a case-control study on 69 patients published by Lovell et al, ${ }^{6}$ as well as from several case series that were published thereafter. ${ }^{7-11}$ More than $80 \%$ of JIA patients showed a response of at least $30 \%$, starting after one month of treatment. After six months at least $70 \%$ of patients showed a $50 \%$ response rate and $50 \%$ of patients had a 70\% response rate. A marked decrease or even loss of morning stiffness and joint pain was noted during the first month of treatment, followed by a decrease in the swollen and tender joint count. The extent of the response during the first three months of our investigation is comparable to the results published by Lovell et al. ${ }^{6}$ In that study 69 JIA patients had been treated initially on an open basis for three months and 51 (74\%) showed a response. The results of the data presented suggest that a three month period is not long enough to assess the therapeutic success rate as at least $30 \%$ of responders continued to improve (to a 
Table 4 Treatment discontinuation according to JIA subgroup and reason for discontinuation*

\begin{tabular}{|c|c|c|c|c|c|}
\hline \multirow[b]{2}{*}{ JIA onset subtype } & \multirow[b]{2}{*}{$\begin{array}{l}\text { Numberstopped/ } \\
\text { treated }\end{array}$} & \multicolumn{4}{|c|}{ Reasons for termination } \\
\hline & & Inefficacy & $\begin{array}{l}\text { Adverse } \\
\text { events }\end{array}$ & Remission & Other reasons $†$ \\
\hline Systemic onset JIA & $17 / 66(26 \%)$ & 14 & 2 & & 1 \\
\hline Seronegative polyarthritic JIA & $12 / 94(13 \%)$ & 4 & 1 & 5 & 2 \\
\hline Seropositive polyarthritic JIA & $3 / 39(8 \%)$ & 1 & 1 & 1 & \\
\hline Oligoarticular JIAł & $9 / 64(14 \%)$ & 3 & 3 & 3 & \\
\hline Enthesitis/arthritis & $5 / 26(19 \%)$ & 1 & 3 & 1 & \\
\hline Psoriasis/arthritis & $4 / 17(24 \%)$ & & 1 & 1 & 2 \\
\hline Unclassified JIA & $3 / 16(19 \%)$ & 2 & & 1 & \\
\hline Others & $4 / 12(33 \%)$ & 2 & & 2 & \\
\hline Total & $57 / 334(17 \%)$ & $27^{*}$ & 11 & $14^{*}$ & 5 \\
\hline \multicolumn{6}{|c|}{$\begin{array}{l}\text { *Including patients with non-JA diagnoses. } \\
\text { †Non-compliance }(n=3) \text {, change in diagnosis }(n=2) \text {. } \\
\text { fln one child with oligoarticular JA a severe flare up of uveitis occurred during a phase of long term remission of } \\
\text { the articular symptoms. } \\
\text { JA, juvenile idiopathic arthritis. }\end{array}$} \\
\hline
\end{tabular}

final figure of about $80 \%$ at the end of the first year). In nonsystemic-onset JIA, about $90 \%$ of patients met the $30 \%$ response level and remained there long term. Apart from the initial paper by Lovell et al, reports on the treatment of JIA using etanercept or comparable biological agents are limited (table 5). Severe adverse events occurred rarely and did not in general limit the applicability of the drug. ${ }^{7-13} 20$
Long term treatment of JIA patients has been documented by Lovell $e a^{20}$ in an open extension study. Forty eight of the 58 patients involved in the controlled trial were observed for two years; $81 \%$ had a response rate of $30 \%, 79 \%$ a response rate of $50 \%$, and $67 \%$ a response rate of $70 \%$. There were 10 withdrawals, seven because of suboptimal clinical response, four of whom belonged to the systemic onset JIA subgroup.

Table 5 Reports on treatment trials with etanercept and similar agents

\begin{tabular}{|c|c|c|c|c|}
\hline $\begin{array}{l}\text { Ref } \\
\text { No }\end{array}$ & $\begin{array}{l}\text { No of patients } \\
\text { (systemic onset) }\end{array}$ & Study design, treatment duration & Description & $\begin{array}{l}\text { Severe adverse events (SAE)/withdrawals } \\
\text { because of adverse events (w) }\end{array}$ \\
\hline 6 & $69(22)$ & $\begin{array}{l}3 \text { month open label study (A) } \\
\text { followed by } 4 \text { month double blind } \\
\text { controlled study (B) }\end{array}$ & $\begin{array}{l}\text { At the end of }(\mathrm{A}) \text { a } 30 \%, 50 \% \text {, or } 70 \% \\
\text { improvement was reached by } 74 \%, 64 \% \text {, } \\
\text { and } 36 \% \text { of patients. In (B), flare up of disease } \\
\text { was more often seen in patients switched to } \\
\text { placebo than in those remaining on the drug }\end{array}$ & $\begin{array}{l}\text { Depression }(n=1) \text {, gastroenteritis/flu-like } \\
\text { syndrome }(n=1) \\
\text { Urticaria (no SAE, w) }\end{array}$ \\
\hline 20 & $58(12)$ & $\begin{array}{l}\text { (B) Open label extension study } \\
\text { up to } 24 \text { months }\end{array}$ & $\begin{array}{l}\text { Long term extension study in } 51 \text { patients of } \\
(A+B) \text { and } 7 \text { patients of }(A) \text {. In } 48 \text { patients } \\
\text { treated for } 2 \text { years a response rate of } 30 \% \text {, } \\
50 \% \text {, and } 70 \% \text { was observed in } 81 \%, 79 \% \text {, } \\
\text { and } 67 \% \text { of patients. Five of } 12 \text { systemic onset } \\
\text { patients terminated prematurely compared } \\
\text { with five of } 46 \text { non-systemic onset patients }\end{array}$ & $\begin{array}{l}\text { Varicella with aseptic meningitis and cervical } \\
\text { subluxation }(n=1, w) \text {; sepsis }(n=1, w) \text {; } \\
\text { abdominal pain }(n=1) \text {; soft tissue infection } \\
(n=1) \text {; peritonitis/appendicitis }(n=1) \text {; } \\
\text { postoperative wound infection }(n=1) \text {; type } 1 \\
\text { diabetes }(n=1) \text {; dental abscess }\end{array}$ \\
\hline 7 & $10(4)$ & $\begin{array}{l}\text { Case series, treatment duration } \\
4 \text { or } 12 \text { months }\end{array}$ & $\begin{array}{l}\text { Improvement of morning stiffness by } 93 \% \text {, } \\
\text { swollen joint count by } 40 \% \text {, tender joint count } \\
\text { by } 88 \% \text {, ESR by } 53 \% \text {. Two patients achieved } \\
\text { clinical remission }\end{array}$ & No SAE observed, no withdrawals \\
\hline 10 & $22(7)$ & $\begin{array}{l}\text { Open prospective trial for up to } \\
24 \text { months }\end{array}$ & $\begin{array}{l}\text { Improvement of swollen joint count by } 49 \% \text {, } \\
\text { tender joint count by } 94 \% \text {, loss of morning } \\
\text { stiffness }\end{array}$ & $\begin{array}{l}\text { Only minor adverse events observed, no } \\
\text { withdrawals }\end{array}$ \\
\hline 9 & $7(1)$ & 6 month open study & $\begin{array}{l}\text { Combination methotrexate and etanercept } \\
\text { treatment showing high efficacy in all } 6 \text { non- } \\
\text { systemic JIA patients and no response in the } \\
\text { other patient }\end{array}$ & No SAE observed, no withdrawals \\
\hline 12 & $8(5)$ & $\begin{array}{l}\text { Retrospective case note review, } \\
\text { treatment duration } 3-10 \text { months }\end{array}$ & $\begin{array}{l}\text { Increased dosage was used in patients failing } \\
\text { the standard dose regimen not yielding any } \\
\text { success in all but } 2 \text { patients }\end{array}$ & Not observed \\
\hline 11 & $10(2)$ & $\begin{array}{l}\text { Case series, treatment duration } \\
4 \text { to }>12 \text { months }\end{array}$ & $\begin{array}{l}10 \text { patients treated with etanercept showed a } \\
\text { comparable response to } 14 \text { patients treated } \\
\text { with infliximab. Approximately } 60 \% \text { reached } \\
75 \% \text { improvement }\end{array}$ & $\begin{array}{l}\text { No SAE and no withdrawals in patients treated } \\
\text { with etanercept }\end{array}$ \\
\hline 8 & $45(45)$ & $\begin{array}{l}\text { Survey, treatment duration 1-27 } \\
\text { months }\end{array}$ & $\begin{array}{l}\text { Survey of systemic onset patients treated in the } \\
\text { USA: } 21 \text { patients showed a sufficient response, } \\
13 \text { a weak response, and } 11 \text { no or a marginal } \\
\text { response. Dose escalation in } 10 \text { patients } \\
\text { produced no significant improvement }\end{array}$ & No SAEs observed \\
\hline 13 & $61(22)$ & $\begin{array}{l}\text { Open label prospective study, } \\
\text { mean duration of treatment } \\
13 \text { months }\end{array}$ & $\begin{array}{l}\text { Maximum } 30 \%, 50 \% \text {, and } 70 \% \text { response rate } \\
\text { were observed at } 3 \text { months (in } 73 \%, 54 \% \text {, } \\
\text { and } 38 \% \text { declining to } 39 \%, 36 \% \text {, and } 26 \% \text { at } \\
12 \text { months of treatment. Response rate } \\
\text { significantly lower in systemic onset patients }\end{array}$ & $\begin{array}{l}13 \text { patients discontinued because of adverse } \\
\text { events: pancytopenia, psychiatric disorders, } \\
\text { uveitis flares, retrobulbar optic neuropathy, } \\
\text { headache, dysaesthesia, the occurrence of } \\
\text { Crohn's disease, vasculitic skin rash, major } \\
\text { weight gain, appendicular abscess, pregnancy }\end{array}$ \\
\hline
\end{tabular}


Five of 12 patients with systemic JIA terminated etanercept prematurely compared with four of 46 non-systemic-onset JIA patients. A lower rate of efficacy of etanercept treatment in systemic onset cases has been described in further small series. $^{8} 1213$

Our analysis of JIA subgroups revealed marked differences in therapeutic efficacy: patients with systemic JIA were less likely to achieve a $30 \%, 50 \%$, or $70 \%$ response level. Discontinuation for lack of efficacy occurred more often in patients with systemic arthritis than in those with other subtypes, indicating that these patients may either be less responsive to treatment with TNF antagonists or they may suffer from more severe disease. As the frequency of systemic arthritis in European studies ranges from $12 \%$ to $14 \%$, a significant number of patients remained untreatable despite the use of TNF antagonists.

A study from France involved 61 JIA patients, 22 of whom had systemic onset disease. ${ }^{13}$ Multivariate analysis showed that systemic onset JIA was associated with a significantly greater risk of not achieving a 30\% improvement. There was a noticeable discrepancy between the findings of this study and those of other studies and case series. The initial response rate was comparable to that of the larger series of patients reported here, as well as those reported by Lovell et al. ${ }^{6}$ However, in the French series the number of patients with a sustained improvement decreased markedly to $39 \%$, in contrast to our data and the trial mentioned above. ${ }^{20}$ The reason for this discrepancy remains unclear. The French investigators had a large number of discontinuations because of adverse events (table 5). Most of these events also occurred in our patients, although with a much lower frequency of discontinuation.

In the present study, the treatment showed an excellent safety profile. The number of non-severe infections was small, although it can be assumed that not all minor infections have been documented. There was a single case report on demyelination, which persisted after discontinuation of etanercept for at least six months in a child with a history of aseptic meningitis and seizures before the introduction of etanercept. So far demyelination has been described in three patients with JIA and in a further 17 arthritic patients treated with either etanercept or infliximab. ${ }^{21} 22$ Discontinuation of anti-TNF therapy resulted in complete or partial resolution of symptoms in all patients. TNF is thought to play a major role in the pathogenesis of inflammatory demyelinating disease of the central nervous system. ${ }^{23-25}$ Therefore, children with JIA treated with antiTNF agents may be at risk for the development of inflammatory demyelination. We suggest that MRI of the CNS should be undertaken, at least in patients with a preceding neurological disease who may be at higher risk.

The therapeutic efficacy of etanercept in chronic uveitis has not been evaluated extensively. In one open trial, a significant fall in cellularity was observed in 10 of 16 affected eyes, and four of 18 eyes showed complete remission. ${ }^{26}$ There were also several children who developed uveitis upon treatment. It has to be assumed that in these patients treatment was not sufficient to prevent or treat uveitis.

\section{Conclusions}

TNF $\alpha$ antagonists open new perspectives for treatment of JIA as they produce dramatic improvement in patients with severe, so far intractable disease. In comparison with adult patients, experience in using TNF $\alpha$ blocking agents in childhood is limited. Current recommendations for treatment with TNF $\alpha$ inhibitors are poorly supported by long term data. Therefore a registry like the one presented here may help to optimise the treatment of a complex and debilitating disease such as JIA. ${ }^{14} 27$

\section{ACKNOWLEDGEMENTS}

The statistics were compiled by M W Eckert, SIMW, Wegberg, Germany. We thank our contributing colleagues in Germany and Austria. Patients were included and data collected by courtesy of the following: H Bollmann, Berlin; M Borte, Leipzig; J Brunner, Homburg; R Bunikowski, Berlin; G Dannecker, Stuttgart; H Deisler, Alsdorf; F Dressler, Hannover; S Ehl, Freiburg; D Föll, Münster; R Gaissmaier, Ulm; N Grosche, Dresden; G Heubner, Dresden; C Huemer, Bregenz; V John, Halle; S Kastner, Krumbach; H D Kettner, Garmisch-Partenkirchen; M Kirschstein, Celle; H Lehmann, Bad Bramstedt; E Miller-Wiegard, Garmisch-Partenkirchen; S Müller, Braunschweig; T Niehues, Düsseldorf; J Quietzsch, Plauen; P Rippberger, Garmisch-Partenkirchen; M Rister, Koblenz; J Roth, Münster; M Sailer-Höck, Innsbruck; U Schoenwald, GarmischPartenkirchen; O Schofer, Neukirchen; M Schöntube, Berlin; O Schofer, Garmisch-Partenkirchen; L Schuchmann, Freiburg; J Stritzel, Bremen; C Vocke, Bremen; D Windschall, GarmischPartenkirchen; O Zimmermann, Chemnitz; A Zurmühl, GarmischPartenkirchen.

\section{Authors' affiliations}

G Horneff, H Schmeling, Department of Paediatrics, University Medical Centre, Martin Luther University, Halle-Wittenberg, Germany

T Biedermann, Department of Paediatrics, Helios Clinic, Berlin-Buch, Germany

I Foeldvari, Paediatric Rheumatology Clinic, AK Eilbeck, Hamburg, Germany

G Ganser, Department of Paediatric Rheumatology, North West Germany Centre of Rheumatology St Josef Stift, Sendenhorst, Germany H J Girschick, Department of Paediatrics, University Medical Centre, Würzburg, Germany

T Hospach, Olga's Children's Hospital, Stuttgart, Germany

H I Huppertz, Prof-Hess-Paediatric Clinic, Bremen, Germany R Keitzer, Department of Paediatrics, Charité, Berlin, Germany

R M Küster, Children's Rheumatology Clinic, Bad-Bramstedt, Germany H Michels, Children's Rheumatology Clinic, Garmisch-Partenkirchen, Germany

D Moebius, Department of Paediatric Rheumatology, Carl-Thiem Hospital, Cottbus, Germany

B Rogalski, Children's Rheumatology Clinic Neckargemünd, Germany A Thon, Department of Paediatrics, University Medical Centre, Hannover, Germany

The registry is supported by Wyeth-Pharma GmbH, Münster, Germany

\section{REFERENCES}

1 Woo P, Wedderburn LR. Juvenile chronic arthritis. Lancet 1998;351:969-73.

2 Brewer EJ, Bass J, Baum J, Cassidy JT, Fink C, Jacobs J, et al. Current proposed revision of JRA criteria. JRA Criteria Subcommittee of the Diagnostic and Therapeutic Criteria Committee of the American Rheumatism Section of the Arthritis Foundation. Arthritis Rheum 1977;20(suppl):195-9.

3 Petty RE, Southwood TR, Baum J, Bhettay E, Glass DN, Manners P, et al. Revision of the proposed criteria for juvenile idiopathic arthritis: Durban 1997. $J$ Rheumatol 1998;25:1991-4.

4 Petty RE. Prognosis in children with rheumatic diseases: justification for consideration of new therapies. Rheumatology (Oxford) 1999;38:739-42.

5 Minden K, Kiessling U, Listing J, Niewerth M, Doring E, Meincke J, et al. Prognosis of patients with juvenile chronic arthritis and juvenile spondyloarthropathy. J Rheumatol 2000;27:2256-63.

6 Lovell DJ, Giannini EH, Reiff A, Cawkwell GD, Silverman ED, Nocton JJ, et al. Etanercept in children with polyarticular juvenile rheumatoid arthritis. Pediatric Rheumatology Collaborative Study Group. N Engl J Med 2000;342:763-9.

7 Kietz DA, Pepmueller PH, Moore TL. Clinical response to etanercept in polyarticular course juvenile rheumatoid arthritis. J Rheumatol 2001;28:360-2.

8 Kimura Y, Li S, Imundo L. Use of etanercept in the treatment of systemic JIA in the USA: results of a survey. Ann Rheum Dis 2000;59:741.

9 Schmeling H, Mathony K, John V, Keyßer G, Burdach St Horneff G. Combination of etanercept and methotrexate for the treatment of refractory juvenile idiopathic arthritis - a pilot study. Ann Rheum Dis 2001;60:410-12.

10 Kietz DA, Pepmueller PH, Moore TL. Therapeutic use of etanercept in polyarticular course juvenile idiopathic arthritis over a two year period. Ann Rheum Dis 2002;61:171-3.

11 Lahdenne P, Vahasalo P, Honkanen V. Infliximab or etanercept in the treatment of children with refractory juvenile idiopathic arthritis: an open label study. Ann Rheum Dis 2003;62:245-7.

12 Takei S, Groh D, Bernstein B, Shaham B, Gallagher K, Reiff A. Safety and efficacy of high dose Etanercept in treatment of juvenile rheumatoid arthritis. J Rheumatol 2001;28:1677-80. 
13 Quartier P, Taupin P, Bourdeaut F, et al. Efficacy of etanercept for the treatment of juvenile idiopathic arthritis according to the onset type. Arthritis Rheum 2003;48:1093-101.

14 Horneff G, Forster J, Seyberth W, Michels H. Empfehlungen der Arbeitsgemeinschaft Kinder- und Jugendrheumatologie zur Therapie mit Etanercept (P75 TNF-Rezeptor- Immunglobulinfusionsprotein). Z Rheumatol 2001;59:365-9.

15 Singh G, Athreya BH, Fries JF, Goldsmith DP. Measurement of health status in children with juvenile rheumatoid arthritis. Arthritis Rheum 1994;37:1761-9.

16 Foeldvari I, Ruperto N, Dressler F, Hafner R, Kuster RM, Michels H, et al. The German version of the Childhood Health Assessment Questionnaire (CHAQ) and the Child Health Questionnaire. Clin Exp Rheumatol 2001;19/suppl 23):71-4.

17 Giannini EH, Ruperto N, Ravelli A, Lovell DJ, Felson DT, Martini A. Preliminary definition of improvement in juvenile arthritis. Arthritis Rheum 1997;40:1202-9

18 Ruperto N, Ravelli A, Falcini F, Lepore L, De Sanctis R, Zulian F, et al. Performance of the preliminary definition of improvement in juvenile chronic arthritis patients treated with methotrexate. Italian Pediatric Rheumatology Study Group. Ann Rheum Dis 1998;57:38-41.

19 Pinnals RS, Masi AT, Larsen RA. Preliminary data for clinical remission in rheumatoid arthritis. Arthritis Rheum 1981;24:1308-15.
20 Lovell DJ, Giannini EH, Reiff A, Jones OY, Schneider R, Olson JC, et al. Longterm efficacy and safety of etanercept in children with polyarticular-course juvenile rheumatoid arthritis. Arthritis Rheum 2003;48:218-26.

21 Mohan N, Edwards ET, Cupps TR, Oliverio PJ, Sandberg G, Crayton H, et al. Demyelination occurring during anti-tumor necrosis factor alpha therapy for inflammatory arthritides. Arthritis Rheum 2001;44:2862-9.

22 Sicotte NL, Voskuhl RR. Onset of multiple sclerosis associated with anti-TNF therapy. Neurology 2001;57:1885-8.

23 Hoffman FM, Hinton DR, Johnson K, Merril JE. Tumor necrosis factor identified in multiple sclerosis brain. J Exp Med 1989;170:607-12.

24 Sharif MK, Hentges R. Association between tumor necrosis factor alpha and disease progression in patients with multiple sclerosis. N Engl J Med 1991;325:467-72.

25 Kollias G, Douni E, Kassiotis G, Kontoyiannis D. The function of tumor necrosis factor and receptors in model of multi-organ inflammation, rheumatoid arthritis multiple sclerosis and inflammatory bowel disease. Ann Rheum Dis 1999;59(suppl 1):132-9.

26 Reiff A, Takei S, Sadeghi S, Stout A, Shaham B, Bernstein B, et al. Etanercept therapy in children with treatment-resistant uveitis. Arthritis Rheum 2001;44:1411-15.

27 National Institute for clinical excellence. Guidance on the use of etanercept for the treatment of juvenile idiopathic arthritis. Technology Appraisal Guidance 2002;35:1-17. 